$\underline{\text { TJSS| vear:2, volume:2, Number:4/2018 }}$

DOI Number: 10.30520/tjsosci.455416

\title{
AL STUDY OF JOYCE'S NOVEL “A PORTRAIT OF THE ARTIST AS A YOUNGMAN” IN THE LIGHT OF MODERNISTIC THEORY
}

Wahid PERVEZ ${ }^{1}$

\begin{abstract}
The present study focuses on the aspects of modernism found in the novel. The most findable aspects of modernism are individualism, stream of consciousness, exile, and loss of faith. This paper highlights the role of modernism in changing thoughts and ways of living. Furthermore it describes modernism as the opener of new door for the people determined to get rid out of the boundaries of family, religion and country. Individualism is the centre of modernistic novel around which all aspects revolve. How modern novel gives preference the inner self of an individual to society's nets and obstacle? This paper discusses in detail the quest of the protagonist of the novel Dedalus who is in search of new ways to see men's role in the world.
\end{abstract}

Keywords: modernism, individualism, stream of consciousness, exile, and loss of faith

\section{INTRODUCTION}

A Portrait of the artist as a Youngman by Joyce is a harbinger of modernism in a response to rapidly changing concepts in religion, social order and capitalism. These all answers come from the actions of Stephen Dedalus.

Dedalus is the main source of the writer through which he demonstrates the inner feeling of an individual. Dedalus says " I will not serve that in which I no longer believe, whether it call my home, my father land or my church. (Joyce, P.191) Dedalus was born in a religious family, was sent to Jesuit school Clongowes Wood College and Belvedere College where the Doctrines of the Catholic faith are instilled in him. His mother and Dean of the studies wanted him to be Jesuit but Dedalus was borne to be a writer, not a priest. To become a writer in the country where religion and people would be under some other country was unacceptable to him. He wanted to seek his own identity and meaning in complexity of modern experience through art, rather accepting the identity given to him by traditional society and culture. He hates Irish society because it is victim of two empires, the British, which control it politically, and Roman Catholic, which rules it spiritually from Rome. Father Arnall's lecture on hell and heaven greatly affects him but his inner self always guided him to follow his own desires. In chapter four he rejects religion when he sees a girl on seashore. At her glance his some aesthetic feelings realize that this is actually is his inner feeling which likes to live independently beyond the boundaries of family, religion, and country. Father of Dedalus was the main source of growing gap between him and his family. Dedalus has

\footnotetext{
${ }^{1}$ University of Sindh Jamshoro, Pakistan, wahidazad1204@gmail.com
} 
experienced severe traumas in the early course of his life. For example, repeated financial troubles always distract his mind from his studies. Dedalus is experiencing religious, national and pressure from his family. His journey to seek the person inside him completes with the epiphany when he had a look of a girl stood before him in midstream opened new door of life. After having a look he felt change in him. He came to know that art is the only field where he can find peace and contentment. By the end of the novel, Dedalus rejects not only Catholicism, but all religions. He said: I tried to love..... It seems now I failed. Dedalus left for Paris leaving country, religion family and friends.

\section{Research Question}

How has James Joyce presented the character of Dedalus in his novel: A Portrait of the Artist as a Youngman?

\section{Research Methodology}

\subsection{Descriptive Qualitative Research}

The present research in its nature is qualitative and employs textual-narrative analysis of the novel " A Portrait of the Artist as a Youngman" from the vantage point Literary Discourse. The collected data for the present paper are descriptive and narrative. Therefore, the qualitative tools like definition, explanation, interpretation are employed to analyze the data and draw generalization and conclusion.

According to Kothari the writer of "Research Methodology: Methods and Techniques" discusses the major purposes of the descriptive research and description of the state of affairs as present. The research can report what has happened or what is happening. (Kothari, 2008, p.3). Moreover, in the eyes of Calmorin et al (2007) Descriptive Research is to find new truth. According to his deep study in the field of research methodology truth may have different forms such as increased quality of knowledge, a new generalization or a new ,law ${ }^{\text {ee }}$, an increased insight into factors which are operating the discovery of new causal relationship, a more accurate formulation of the problem to be solved and many others” (p. 70)

\section{Data analysis / discussion}

\section{INDIVIDUALISM}

"This race and this country and this life produced me, he said. I shall express myself as I am.” (Joyce, P, 156)

Individualism is the idea that freedom and thought of action for each person is the most important quality of a society, rather than shared effort and responsibility. (Cambridge Advanced Learners)

Individualism is the main aspect of modernism which gives rise to other aspects of modernism. In this aspect character's personality, his thoughts, likes and dislikes remain primary concern of the writer. In the same way Dedalus as a modern hero breaks restrictions of family, church and nation to form his own destiny according to his inner light. He defeats the limitations of his cultures and environments, and disentangle himself from these knots and ties.

In childhood Dedalus is completely integrated into his little world. He is hardly able to put together a coherent stream of thought. Dedalus's confusion as a small boy in a strict 
Jesuit school, his discontent with his father and the financial situation of the family and his growing feeling of alienation made him mentally exile. In adolescence, Dedalus goes to prostitution and gives in to lust. Later, he becomes religious and even considers entering priesthood. In his ways many walls raised but he demolishes every obstacle comes between him and his desire. At the end of chapter four at what is really the climax of the novel; Dedalus has vision of becoming an artist. His journey to seek the person inside him completes with the epiphany when he had a look of a girl stood before him in midstream her look opened new door of life for him. After having a look he felt change in him. He came to know that art is the only field where he can find peace and contentment. By the end of the novel, Dedalus rejects not only Catholicism, but religion all tougher .He said: I tried to love.... It seems now I failed. Dedalus, left for Paris leaving country, religion family and friends.

"When the soul of a man is borne in this country there are nets flung at it to hold it back from flight, you talk to me of nationality, language religion. I shall try to flight by those nets" (Joyce, P, 157)

Joyce wants to say in these lines that Ireland is an independent country but even though it can't take its decision its own. Its political decisions are taken by England and its Church is controlled by Rome. In Ireland Roman Catholic religion is strictly followed. A child born in catholic family can't become anything except a Jesuit. In Ireland English language was spoken that is considered borrowed language. Joyce shows peoples' unawareness of their own language in the novel. Dedalus also experiences in the novel. His Catholic family, Catholic school and Catholic country were main hindrances to his success. He considered to be in Ireland is to be a slave. He even dislikes to live in the country that's power would be in other country's hand. Therefore, Dedalus decides to leave everything that comes in his ways. He left for Paris leaving his family, religion and country behind.

"I will tell you what I will do and what I will not do. I will not serve that in which I no longer believe, whether it call itself my home, my father land, or my church and I will try to express myself in some mode of life for art as freely I can and as holy as I can, using for my Defense the only arms allow myself to use silence exile and cunning." (Joyce, P, 191)

In discussion with Cranly, Dedalus clearly says that he does not believe in religion and hates to live in his country. In Ireland he was bound between two opposing ideas, one is religious and other is his own thought and feeling. His family and Catholic religion has limited his thought. He wanted to be a writer but his family and school has left only one opportunity for him and that was priesthood. He belonged to such family there he could only become a Jesuit. He had known that to live in Ireland is to live in prison. There was no solution for him except to escape. England and Rome were ruling Ireland. He decides to leave for Paris because there he would be away from bondage of family, religion. "I do not fear to be alone or to be spurned for another or to leave whatever. I have to leave. And I am not afraid to make a mistake, even a great mistake, lifelong mistake and perhaps as long as eternity too.” (Joyce, P, 191)

Joyce discusses boldness of modern people. People in modern age took their decision fearlessly. To fulfill their desire they did not care of any loss. To represent an example of modern man Joyce portraits the character of Dedalus. His courage was shown throughout the novel. After realizing his exact interest he decides to become an artist. 
He adamantly determined to become a writer for which he was ready to do anything. His experiences since childhood to young hood made him experienced that family, religion, beloved, friend all were those forces which prevent to do what he wanted to do. That's why Dedalus took out one solution to be saved from all these forces. He took final decision to escape from the country and that was best solution at his glance. Neither he would be available in the country nor could anyone have access to him.

Welcome, O life! I go to encounter for the millionth time the reality of experience and to forge in the smithy of my soul the uncreated consciousness of my race" (Joyce, P, 196)

These final lines of the novel proclaim Stephen's aim to be an artist for the rest of his life. The phrase "the smithy of my soul" indicates that he strives to be an artist whose individual consciousness is the foundation for all his work. The reference to "the uncreated conscience of my race" implies that he strives to be an artist who uses his individual voice to create a voice and conscience for the community into which he has been born. The final its reference to" old father" and" old artificer," reinforces Stephen's two fold mission. He invokes his "old father" which can be read as either Simon Dedalus or Ireland itself to acknowledge his debt to his past. He invokes the "older artificer" his namesake Dedalus, the master craftsman from ancient mythology to emphasize his role as an artist. He is through his art that Stephen will use his individuality to create a conscience for community.

\section{STREAM OF CONSCIOUSNESS}

The term was coined by Henry James in principal of psychology (1990). The modernist writers excessively used this term in their books that way the novels produced in this period are called stream of consciousness. Cuddon says "now an almost indispensable term in literary criticism, it refers to that technique which seeks to depict the multitudinous thoughts and feelings which pass through tne mind.” (Cuddon, P, 866)

Acceding to this term novelist discusses the characters' ideas. This is basically a technique used in literature to convey how characters feels or what the characters think. The characters' emotions are portrayed either through hints within dialogue or actions taken by the characters in certain situations.

A portrait of artist as a Youngman is a stream of consciousness novel because the narrator is not only telling a story but also states the state of mind of characters. Joys used this term technically in this novel. He basically discovered the mental state of modern people and to do this Joyce used Dedalus his source to convey this idea. Joyce used the third person to describe the experiences of Dedalus we first encounter stream of consciousness at the beginning of the book when Dedalus is a chilled pores, as, in the opening lines:

“Once upon a time and very good time it was along the road met a niceness little boy named baby tucked. (Joyce, P, 1)

The pressures from expectations gradually become a burden and his soul searches finally results in art mea of breaking the cage. To Dedalus art was nevertheless a way of liberating his soul by fulfilling his hunger for meaning not with what was imposed upon him by others but by something originating from inside himself. Stephen's path to becoming an artist very step while going though the novel. His first eat of courage, Independence and rebellion is where he porters his palm-whipping later on, he would 
also commit hers say when writing a school essay and reject priesthood. The gradual gap between him and his family especially his father is ever more obvious as time pass. Dedalus has experienced severe traumas in the early course of his life, namely repeated financial troubles which Dedalus was a witness of and the deep are the questions of religion and patriotism with his own family.

"As the train streamed out fog the station he recalled his childhood wonder of years before and every event of his first day at Cologowes". (Joyce, P, 66)

Dedalus passed crucial days at Colongowes. In childhood Dedalus was so simple. He was just an observer. In train he recalled the days when he was having lunch with his family. He remembered how they were having discussion over religion and politics. Dedalus's experience at school was worst which he never forgot. He was badly treated by bullies of class.

"And not to have any one person, Cranly said who would be more than a friend, more even than the noblest and truest friend a man ere had. (Joyce, P, 191)

Joyce highlights the feeling and thinking of Cranly. He was disheartened by Dedalus. Dedalus's straightforward comments of to live alone in another country shocked him severely. In loneliness, Cranly thought that how cruel Dedalus had become that he even had not care of his close friend. To live friendless was main issue on which cranly was thinking. Cranly was upset and pondering over the thinking of his friend.

."Constant voices of his father and master urge him to be a good catholic above all things. When the gymnasium had been opened he had heard another voice urging him to be strong and manly and health and when the movement towards the national revival had begun to be felt in college yet another voice had bidden him to be true to his country and help to raise up her language and tradition” ( Joyce, P,68)

Joyce's use of stream of consciousness technique in these lines is quite obvious. Dedalus is shown under pressure of family and religion in him. His family's gradual expectation from him was increasing burden on his personality. The clash between his and his family's desire put him into the state of dilemma. His family wanted him to be priest and he wanted to be a writer. He always remained in dilemma that what he should choose. But as a modern man he revealed the secret what an individual should do. In spite of family's pressure and strict rules of catholic school he preferred his desires to them. He had heard the inner voice of hidden man.

\section{Exile}

"He had known neither the pleasure of companionship with other nor the vigor of rude male health nor flail piety nothing stride within his soul but a cold and cruel and loveless lust. His childhood was died or lost and with it his soul capable of simple joys and he was drifting amid life like the barren shell of the moon.” (Joyce, P 72-73)

A person who lives outside his own country either from choice or he is forced to do so. Stephen Dedalus's nature of exile is twofold. Firstly he was mentally and secondly physically exile. His physical exile at the end of the novel shows that he was not escaping from Ireland but he was escaping with it. His mind was totally different from the rest of family members. His family's downfall, strict rules of religion and country's position like a slave caused his mental exile. The sense of separation aroused in him from the time he started searching for the man inside him. The man inside him rejected 
to follow all imposed rules. His mental exile was due to his nature that never let him accept any law and orders against his desire. He was determined to achieve that suited to his personality. His quest of suitable field for his personality made him mentally exile.

"I do not fear to be alone or to be spurned for another or to leave whatever. I have to leave. And I am not afraid to make a mistake, even a great mistake, lifelong mistake and perhaps as long as eternity too.” (Joyce, P 191)

Physical exile of Dedalus was another outlook of his mental state. He hated to live in the country that was despite of being independent ruled by another country, there, leaving national language borrowed language was given preference and spoken. Ireland was politically governed by England and religiously by Rome. It seems as if Ireland was colonized by these two powers. Dedalus even did not accept to live in the country that was itself slave of others. He did not leave only his friends, love, family, religion but to completely unentangle himself he left for Paris.

\section{Loss of faith}

"His destiny was to be elusive of social and religious orders. The wisdom of the priest appeal did not touch him to the quick. He was destined to learn his own wisdom apart from others or to learn the wisdom of others wandering among the snares of the world." (Joyce, P,111)

Joyce raised the issue of religion in his novel which shows religion is also one of the main hindrances to success for modern people. In character of Dedalus we see him rejecting religion to become an artist. Joyce used Dedalus as a tool to respond that how an artist can have a journey to achieve his goal. Dedalus grew up in catholic family, he was sent to a strict Catholic boarding school where he spent his childhood days those were painful and unforgettable for him. He was teased by bullies of the school, pandied by teacher unreasonably and forced him to be priest. Dedalus was tied between two different concepts. One is Catholic Church and other is his own thoughts and feelings. His struggle was shown in the novel that how Dedalus since childhood struggled to choose his best. In young hood he had the ability to chose right way, slowly and gradually he experienced and finally found appropriate place in writing.

He was always said to become a priest but he was never asked what he wanted to be. Modernism highlights issues of individual's interest that was always crushed by family and religion. His belief in religion was weak. He was compelled to be religious. He never felt desired relief for what he was looking. To find satisfactory place for the man inside him he visited different prostitutes but in their company he found only source of luscious desire. After lecture of Father Arnal on torment of hell he returned to religion. He asked forgiveness of God and determined not to return to prostitution. But his this confession could not stop him to find out the field which his inner-self demands.

His journey to seek the person inside him completes with the epiphany when he had a look of a girl stood before him in midstream. Her look opened new door of life for him.

"her image passed into his soul forever and no word had broken the holy silence of his ecstasy. Her eyes called him to and his soul had leaped at the call. (Joyce, P, 132)

After having a look he felt change in him. He came to know that art is the only field where he can find peace and contentment. By the end of the novel, Dedalus rejects not 
only Catholicism, but religion all together .He said: I tried to love..... It seems now I failed. Dedalus, left for Paris leaving country, religion family and friends.

\section{CONCLUSION}

The study concludes that modern era generated new ideas in people. Modernism provided the main idea of an individual's importance. Modernism gave rights to every person to live according to their disposition. The term "Stream of consciousness" remained main technique of modern novels. This is also one of the key elements of modern novels. Modern novels propagated an idea under that an individual should not care about anyone or anything if they try to become obstacle in ways of his success. To achieve his goal a person can leave his family, religion, friends, beloved and even country. Different elements of Modern novel discuss mental and physical exile of protagonist of the novel Stephan Dedalus. He rejects religion to become an artist. Because, being a member of a catholic family to become an artist was impossible.

\section{REFERENCES}

[1]. The Essays of Virginia Woolf, vol III, ed. Andrew Mc. Neillie, London, Hogarth Press, (1986- 1994),p435

[2]. The Essays of Virginia Woolf, vol III, ed. Andrew Mc. Neillie, London, Hogarth Press,(1986- 1994),p435-436

[3]. Jose Ortega y Gasset, The Dehumanization of Art and Ideas and the Novel, Princeton: Princeton University Press, 1948, p 38

[4]. Deborah Parsons, Theorists of the Modernist Novel: James Joyce, Dorothy Richardson, Virginia Woolf, Routledge Critical Thinkers, London and New York, 2007, p15

[5]. Kime Scott Bonnie, The Gender of Modernism, Bloomington, Indiana University Press,1990, p16 [6]. The Essays of Virginia Woolf, vol IV, ed. Andrew Mc. Neillie, London, Hogarth Press,(1986-1994),p 160 